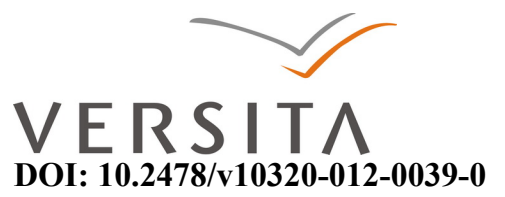

\title{
LILIES ON THE LAND - THE FORGOTTEN WOMEN'S LAND ARMY OF WORLD WAR II - A DOCUMENTARY PLAY
}

\author{
HILDEGARD KLEIN \\ University of Malaga, 29071 Málaga, Spain \\ hklein@uma.es
}

\begin{abstract}
This paper centres on a play directed by Sonia Ritter and produced by the Lions part that portrays an extraordinary event in Britain's recent history - the Women's Land Army of World War II. It is based on real evidence given in hundreds of letters and interviews with former Land Girls. The anecdotes of their shared experience and strenuous work are presented by a female quartet - Margie, Peggy, Poppy and Vera - in a sparkling, captivating and emotional way.
\end{abstract}

Key words: agricultural labour, historical testimony, Lions part, Women's Land Army, World War II.

We are land girls, we are land girls,

And we're proud to do our bit,

Working, hoeing, reaping, sowing,

Just to keep the nation fit. [ ...]

To the tune of "Oh, My Darling Clementine"

(Lilies on the Land 2010:25)

\section{Introduction}

\section{1) The creation and development of documentary theatre}

Lilies on the Land can be classified as documentary theatre or theatre of testimony because it is based upon real historical events, that is, real happenings. According to Mason, "[d]ocumentary Drama presents and re-enacts records from history. Unlike traditional drama, it is not founded on a freely imagined plot" (1977:263). Documentary 
drama can be traced back to Erwin Piscator's production of In Spite of Everything (Trotz Alledem) in 1925, in which “he depicted Germany's history from Berlin's situation at the outbreak of World War I to the assassination of Karl Liebknecht in 1919" (Mason 1977:263). Mason also explains that "Piscator insisted throughout on the factual authenticity of his material, claiming that "the whole performance was one huge montage of authentic speeches, articles, newspaper clippings, slogans, leaflets, photographs and films of the War and the Revolution" (263). Note Piscator's emphasis on the importance of dramatising real happenings, real historical events which he points out as being the essence of the documentary method, that is, to construct a theatre of involvement through documents. Bertolt Brecht, in turn, is another key figure in the history of drama who influenced the new wave of documentary drama, but he differed from Piscator "in wanting above all to maintain an aesthetic distance between the stage and the audience" to provoke the spectator's rational reflection, rather than draw him into emotional involvement (Mason 1977:267). It is relevant here to refer to Joan Littlewood's famous, time-breaking documentary play Oh What a Lovely War, produced in 1963 . The play was staged as a multi-media event, with the introduction of non-naturalistic theatrical devices, such as news panels, slide screens, pierrot shows and music-hall entertainment to draw attention to the absurdities and atrocities of war (here the First World War). The play seeks to satirise patriotism and heroism, and thus follows Brecht's theory of both alienating and engaging the audience in establishing a rational analysis of the action. Brecht's theory of stressing aesthetic distance was followed by a number of documentary dramatists such as Rolf Hochhuth, Peter Weiss and Heinar Kipphardt. Favorini (1995:139-45) in Filewod (2009:60) points out that Weiss, “whose 1968 essay, 'Fourteen Propositions for a Documentary Theatre', articulated the principles of arguments, montage and critical examination he attempted to achieve with his 'oratorio' documentary of the Frankfurt Auschwitz trial, The Investigation" (1964-5). The play "includes harrowing testimonies from witnesses of the concentration camps" and was "poignantly restaged $[\ldots]$ at the Young Vic in 2007, in a new eighty-minute version by the philosopher Jean Baudrillard that created a chilly, contemporary resonance" (Lane 2010:59). Considered a key figure as the creator of the "Theatre of Facts", Weiss lectured on the subject of documentary theatre at the Berliner Ensemble in 1968. "For Weiss, 
documentary theatre is a utile form that marshals a 'critique of concealment', 'distortion', 'lies' and the 'artificial fog' generated by media and government" (Megson 2009:198). In fact, "Weiss's 1971 definition of documentary theatre is pertinent today because he affirmed the dialectical relationship between raw material and the theatrical apparatus" (Bruzzi 2006:6 in Reinelt 2009:9), that is to say, the document produces the raw material that is used in theatre performance. "This link sets up a realist epistemology where knowledge is available through sense perception and cognition linked to objects/documents" (Reinelt 2009:9). In this connection, Carol Martin has pointed to an important feature of documentary theatre: to reproduce "what really happened". She writes: "While documentary theatre remains in the realm of handcraft - people assemble to create it, meet to write it, gather to see it - it is a form of theatre in which technology is a primary factor in the transmission of knowledge" (2006:9). In the absence of "real people" on stage, their stories are re-enacted and represented through various means, including stage acting, film clips, photographs, and other "documents" that attest to the veracity of both the story and the people being represented. Martin stresses: "Technology is often the initial generating component of the tripartite structure of contemporary documentary theatre: technology, text, and body" (2006:9). In fact, in the last twenty years, documentary theatre and even more so "verbatim" or tribunal theatre has enjoyed great popularity in its tackling of socio-political realities in the mode of "infotainment". (The term "verbatim theatre" was coined in 1987 by Derek Paget in a paper for the New Theatre Quarterly (Lane 2010:59). These plays claim that "what you will hear spoken are the authentic and unaltered words of various real-life agents" (Reinelt 2009:13), and their only sources are official transcripts of judicial proceedings and/or interviews. The case for documentary theatre arose from the "failure of new British writers to engage with the political" and "[t]he failures of the media to faithfully report events without manipulating evidence" (Lane 2010:61). Documentary theatre, thus, stresses its moral and ethical claims to truth (Martin 2006:14). "Governments spin the facts in order to tell stories", whereas "[t]heatre spins them right back to tell different stories" and to avoid social reality being "constructed" (2006:14). In an age of globalisation, poststructuralism and postmodernity, theatre practitioners have included new technology, media, archive documents, memory and testimony together with the body to present on stage past and 
present political subjects, matters of public weight and interest. In the decade after 2000, the Tricycle Theatre continued its tradition of staging verbatim tribunal plays with Richard Norton Taylor's Justifying War: Scenes from the Hutton Inquiry” (2003), about the death of weapons expert David Kelly; David Hare, in his turn, wrote Stuff Happens (2004) - the title being taken "from the offhand response of Donald Rumsfeld [...] to news of the looting of Baghdad in April 2003" (Sierz 2011:73) -; Victoria Brittain and Gillian Slovo Guantanamo: 'Honor Bound To Defend Freedom' (2004); and there was Robin Soans' timely Talking to Terrorists (2005), (performed in the same week as the 7/7 London bombings). Many of the titles of these documentary/verbatim plays are "selfexplanatory", in Sierz's words (2011:73). Here we have selected a few documentaries as an example of the wealth of plays with political and historical themes performed in very recent years.

\section{Production development of Lilies of the Land}

The above short outline of the features of documentary drama is intended to prove that Lilies on the Land can be included in this dramatic genre. It is certainly "infotainment" as it supplies interesting information about a historical period and, at the same time, it is a highly entertaining piece because of its liveliness. The play developed from about 140 letters from former Land Girls who responded to an article in Saga Magazine to send any material relating to their experiences in the Second World War Land Army. In the Introduction to the play, the company members of the Lions part (this company evolved from the Royal Shakespeare Company) explain that the "letters flowed in from women from all walks of life; memories and recollections, anecdotes, poems, photos, newspaper cuttings and wartime memorabilia" (2010:v). The director of the company, Sonia Ritter, relates that the company was "amazed at the breadth of human experience", and "the depth and dignity of each individual woman's experience". Many women were interviewed to tell their stories personally, and "they recounted them with clarity and vivacity" (2010 Theatre Programme: no page number).

The project of staging a play about the ex-Women's Land Army arose from the idea of paying homage to this Forgotten Army. The company explains: "We began to realise that we knew little about the extraordinary role the Women's Land Army played 
in World War II: certainly a Forgotten Army" (Introduction 2010:v). In fact, Ritter affirms that the "forgotten" army was not familiar to her. Significantly, hardly any credit had been given to the organisation and its members; the women had received no significant post-war pension or honour. Ritter's interest in the Land Army was kindled when, in a book of war poetry, she started to read poems by Land Girls (mostly unknown) that related their experience as farm labourers (Theatre Programme: $n / p$ ). The play was devised as a counter-piece to the Lions part production of Christopher Fry's $A$ Sleep of Prisoners, produced in 2001, which "explores the troubled minds of four soldiers held as prisoners of war" (Introduction: v). Lilies on the Land dramatises the wartime experiences of those women who dedicated their lives to the welfare of Britain during the War.

\section{Historical outline of the Women's Land Army}

In the Theatre Programme presented by the Arts Theatre, London, where the play was first performed on 8 June, 2010, Emma Butler Smith offers a historical outline of the origin of the Women's Land Army. It had its roots in the shortages of World War I, when 50 percent of Britain's food was imported. There were serious harvest failures in 1917 and the menace of German naval blockades meant that the country was left with only three weeks' reserve of food. Out of this pressing need for survival, Miss Meriel Talbot and Lady Gertrude Denman, members of the just founded Women's Institute, were appointed to organise the first Women's Land Army (WLA). The response was startling as 23,000 women were admitted into the Army in 1918.

At the outbreak of World War II in 1939, Britain faced an analogous situation. Butler Smith explains in the programme that "Britain was importing about 70 percent of its food, but needed to be as self-sufficient as possible" (Theatre Programme: $n / p$ ). Between September 1939 and March 1940, over 30,000 agricultural workers were enlisted in the army, causing an alarming shortfall in farm labourers. Out of this necessity, on June $1^{\text {st }} 1939$, the second WLA was officially formed. The official minimum age was 17 , and women joined for all kinds of reasons - patriotism, to avoid munitions work, to escape home life and for a healthy country life (Butler Smith, $n / p$ ). The women were attracted by alluring recruitment posters that presented an idealised 
picture of the land and land work, following the slogan "Join the Women's Land Army. For a healthy, happy job". However, they mainly found exhausting and demanding hardships, working about 50 hours per week, from dawn to dusk, for about 28 shillings a week (42 pounds today), half of which was normally deducted for board and lodgings, which they had to share with other workers, or with the farmer and his wife. The hygiene conditions were often appalling, and many of them were chronically underfed. "At its peak in 1943, the WLA had nearly 90,000 members and produced two out of every three meals eaten in Britain. Between 1939 and 1950, 250,000 women were members" (Butler Smith, Programme n/p). However, the number gradually decreased and the Army was officially disbanded in October 1950.

\section{Staging and performing Lilies on the Land}

The play Lilies on the Land does present genuine historical testimony of women's work in the WLA and the jobs they had to do to keep a farm functioning: threshing, milking, ploughing, reclaiming land, rat-catching, crop-picking, hedging, ditching and handling farm machinery designed for sturdy men and difficult for women to operate. The time scheme is expertly chosen, and, as it says in the Introduction to the play (2010:vii) "[t]he nature of time in Lilies on the Land is fundamental to its dramatic power". Each story in the play is realised "physically and emotionally in the moment it is told, - in 'real time' - not as something that is being recalled with nostalgia" (vii). The company goes on to explain: "Whilst the inspiration that fires the women to speak, sparks from Sir Winston Churchill's death, and the era they recall is some twenty-five years before, the dynamic of the telling is in the present, to a twenty-first-century audience" (vii). In fact, "[t]he three timelines co-exist and move together, creating the shape of the theatrical experience: January 1965, 1939-45, and now. Apart from the lively women characters, who hold the audience's entire attention, "there are two other principal characters in Lilies on the Land: World War II and the land itself, both surrounding and underpinning all that happens to the women" (Introduction: vii). Obviously, the action is concerned with the women's working experience on the land during the war. The structure of the play is circular, beginning with the BBC's announcement, in 1965, of Winston Churchill's death (2010:5) and ending with the four women "watching the 
funeral cortege of Churchill pass by" (50) while the muffled bells of St Paul's Cathedral can be heard.

Churchill's celebrated speech of May 1940, initially delivered in Parliament and later broadcast, in which he reiterates "We shall fight [...] We shall never surrender [...]" (6) establishes the transition from his death to the beginning of the war, autumn 1939. It connects to the women recalling why they joined the Women's Land Army. They relate that they were attracted by the 'darned' poster: "A girl, head held high, golden hair, smiling and proud [...] On a hayrick" and the slogan: "Lend a Hand on the Land" (6). In fact, the women remember their bucolic picture of the land: "Green fields [...] Crops of vegetables. Perhaps flowers. All things bright and beautiful" (6). As the play unfolds, this picture gives way to all sorts of hardships. Apart from their initial attraction to the land, they were also intrigued by the uniform which consisted of a jumper and breeches, especially as most women in this period were not allowed to wear trousers at work. Interestingly, while the women's memories travel back in time as they give their reasons for joining the Army, they "reveal Land Army uniforms under their clothes", while they sing a well-known song from the war years: "Wish Me Luck as You Wave Me Goodbye" (10). The framework of the whole play is consequently based on the women's memories, related in their letters with outstanding vivacity and excitement. The four actresses of the 2010 Arts Theatre production - Dorothy Lawrence, Kali Peacock, Sarah Finch and Rosalind Cressy - succeed in transmitting this exceptional enthusiasm. Their individual, coherently intertwined stories narrating their personal journeys have an epic character, and their narrative is structured like a succession of interwoven monologues. However, as "the four performers interact, chuckling, wincing or nodding sympathetically at each other's stories" (Marlowe 2010:663), the performance acquires an extraordinary liveliness, speed and intensity, which is highlighted by the many period songs (about fifteen) that are reproduced and sung by the four actresses.

The time scheme the play follows is very skilfully devised. As the action develops in the countryside, it tracks the four seasons of a year, and, very dextrously, it furthermore illustrates the duration of the war, though it lasted not one, but six years, "covering the whole war from 1939-45" (Spencer 2010:663). It is pertinent to mention in this connection the poem The Land, written by Vita Sackville West in 1926, because of 
its cyclical nature, as the poem is divided into four sections according to the four seasons. Its structure and subject matter evoke Virgil's Georgics, but instead of conjuring up a bucolic idyll, The Land recounts "the mild continuous epic of the soil" with robust descriptions of the selfless toil of ploughmen, craftsmen, beekeepers and shepherds. The poem is a didactic hymn to the Kentish countryside and an evocation of the cultivated landscape and its wildlife (2004: Dust Jacket Front Flap). Similarly, in Lilies on the Land, the initial notion of working in a bucolic environment gives way to an epic tale of backbreaking work and hardship, endured with perseverance, courage, and unyielding stamina.

The four women who narrate their war experiences on the land are representatives of all conditions of life, that is, from four distinct social classes. We have adapted the following descriptions from the character list provided in the edition of Lilies on the Land (2010:2):

Margie is from Newcastle. She refers to herself as a townie. She is very naïve and childlike though not childish. Appearance-wise, she is pretty, with masses of curls. She is warm and constantly in a state of surprise. She is funny and affectionate. She was brought up a Methodist. Margie signed up because she was attracted by the uniform and expected to pick fruit and vegetables in the sunny South of England.

Peggy is a happy, confident young cockney from a large East End family - that is, until she finds herself in the middle of the country, not knowing "one end of a cow from the other". During her time in the Land Army, Peg maintains her sense of humour and her positive attitude [...] most of the time. She enjoys the work, revels in the camaraderie of the other girls, but also loves to be on her own in the field on her tractor - her ploughing skills are second to none!

Poppy is from Oxfordshire, brought up in a happy and privileged family and used to a comfortable lifestyle. Her accent is RP. She signed up enticed by the romantic posters. The tough life on the land is a shock, but she is ready to learn, and throws herself into it all with energy and enthusiasm, finding the strength [...] within herself to cope. A confident and outgoing person, she enjoys dances and romance, and, eventually, life on the land.

Vera is educated, and frustrated with old-fashioned views of women. The war is an opportunity for her to get away from her snobby stepmother and to go out into the world and find out who she really is. She is a complex character, and perhaps she'll never be satisfied with life. Competent and hearty, she is in some ways the most lonely of the four Land Girls, and probably the only one who's read Virginia Woolf. 
As mentioned before, the stories these four women narrate are an amalgamation of the numerous letters received from former Land Girls and they constitute "a cornucopia of revealing historical detail and amusing anecdote", as Shore (2010:739) has said. Indeed, the recounting of their work presents a comprehensive insight into the different tasks that had to be done on the land. As none of the women had been prepared for the hardship ahead of them, many of the stories told contain amusing and comical notes, but they also offer detailed descriptions of the land work to be done. At times their narration acquires a choral quality as the four women recount some of these tasks:

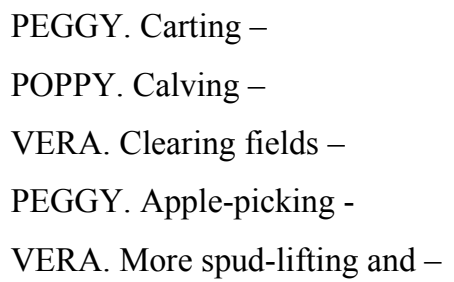

ALL. Threshing (16).

Thus, we are given a historical insight into the type of work on the land, either by hand or with the help of some now old-fashioned, heavy machinery (the noise of which is created by the girls while they repeat the following words):

PEGGY. The threshing machine's worked by an old steam engine, which belches out disgusting smoke. When moving the machine from farm to farm - metal cleats have to be removed from the wheels and bolted on again by us girls - hard on the hands.

POPPY. One girl has to climb onto the stack and throw sheaves onto the machine with a pitchfork. PEGGY. Another girl stands in a sort of well next to a drum, with a knife attached to her wrist with a strap, she's called the band-cutter.

VERA. The feeder catches the stook and the band-cutter slides the knife in flat, and flicks it back to cut the string, grabs the string by the knot.

ALL. You never wasted string.

PEGGY. The feeder then fans the sheaf out onto the drum, which moves along a canvas belt. POPPY. The threshed corn comes out at the other end to be poured into sacks and loaded onto a cart. (16-17). 
Apart from the main women characters, the four actresses play twenty-eight other parts - for instance, grumpy farmers, cheeky labourers, American GIs, German and Italian prisoners of war, farmers' wives, imitating their voices and gestures. These doublings contribute significantly to the enormous liveliness and hilarity of the performance.

However, the comical notes are interrupted by more serious ones when the women recount their terror on hearing doodlebugs falling out of blue skies, landmine craters in a neighbouring meadow, and, naturally, anguish for their distant loved ones. We also hear of sadistic bullying and sexual harassment by foremen and Italian soldiers. Poppy relates that she "never knew a moment's peace" because the foreman "would jump out from behind the barn door ... and grab (her)" (41), while Vera recounts her traumatic experience when she was being hunted by an Italian chap: "[H]e jumped out at me, grabbed me round the waist and pushed me against the wall" (41). After the narration of the girls' appalling experiences they sing: "When this Lousy War is Over, no more Land Army for me $[\ldots] "$ (42).

The girls' hard and constrained lives achieve a welcome exhilaration and distraction by the arrival of American servicemen, who invite them to weekend dances to the rhythm of the latest popular music, and to share sumptuous food (in contrast to their meagre meals). A further change in their monotonous lives is produced by the appearance of Italian and German prisoners of war (POWs) who are to join them in their farm work. Each nation, as Evans (2010:663) writes, "conforms to stereotype". The Italians were lazy workers, but sociable and talkative, while the Germans were hard-working and friendly, but homesick and downhearted. The girls were amazed that they were not Nazis at all, but "just ordinary people" (35).

The women's testimony of their war experience and the documentary format of the play is reinforced when their narrative is interrupted by a series of BBC recordings that transmit the latest war news, such as broadcasting the London Blitz in 1940, the Japanese entry into the war in 1941, the bombing of Nuremburg in 1944, etc. (See pages $21,25,30,37,42, \& 46)$. However, it is mainly the authentic voices of the Land Girls that recount a genuine historical record of the life and work in the British countryside during the war. 


\section{Conclusion}

The play reminds us of the neglect so many women suffered while doing silent heroic work. As mentioned before, the Women's Land Army had received no post-war pensions or honours, nor at the time were they acknowledged on Remembrance Day. It was not until 2000 that the WLA were invited for the first time by the British government to pay their respects at the Cenotaph, and in 2008, after years of campaigning, the 20,000 surviving members of the WLA were finally awarded commemorative service medals.

Sonia Ritter and the Lions part have succeeded in vindicating the silent and heroic work of the Women's Land Army which contributed so significantly to the provision of food for the British people during the war. They have provided a vital and important historical testimony in this documentary play through the lively quartet of four brilliant actresses who represent the wide variety of women who formed the Land Army. Furthermore, the company has successfully portrayed historical events in a highly theatrical and appealing mode.

The following statement delivered by Molly Stevens, a former land girl from Oxfordshire, may represent most of the women's voices:

\footnotetext{
You took up the fight and that was it. We all survived, and I'd do it all again tomorrow (Theatre Programme:n/p).
}

\section{References}

Bruzzi, S. 2006. New Documentary: A Critical Introduction. $2^{\text {nd }}$ ed. London and New York: Routledge.

Butler Smith, E. 2010. Lilies on the Land. Theatre Programme Arts Theatre, London.

Evans, L. 2010. "Spectator" in Theatre Record, Vol XXX (12).

Favorini, A. 1995. Voicings: Ten Plays from the Documentary Theatre. Hopewell, NJ: Ecco Press.

Filewod, A. 2009. "The Documentary Body: Theatre Workshop to Banner Theatre” in Forsyth, A. and C. Megson (eds.). Get Real: Documentary Theatre Past and Present. Houndmills, Basingstoke: Palgrave Macmillan.

Finch, S., D. Lawrence, K. Peacock, S. Ritter, N. Tamar and the Lions part. 2010. Lilies on the Land. London: Nick Hern Books.

Forsyth, A. and C. Megson (eds.). 2009. Get Real. Documentary Theatre Past and Present. Houndmills, Basingstoke: Palgrave Macmillan.

Lane, D. 2010. Contemporary British Drama. Edinburgh: Edinburgh University Press. 
Marlowe, S. 14/06/10. "The Times" in Theatre Record, Vol. XXX ( 12).

Martin, C. 2006. "Bodies of Evidence" in The Drama Review, Vol 50 (3) (T191, Fall), pp.8-15.

Mason, G. 1977. "Documentary Drama from the Revue to the Tribunal” in Modern Drama, 20 (Sept.), pp.263-277.

Megson, C. 2009. "Half the Picture: ‘A Certain Frisson' at the Tricycle Theatre” in Get Real: Documentary Theatre Past and Presemt. Houndmills, Basingstoke: Palgrave Macmillan.

Reinelt, J. 2009. "The Promise of Documentary" in Forsyth, A. and C. Megson (eds.). 2009. Get Real. Documentary Theatre Past and Present. Houndmills, Basingstoke: Palgrave Macmillan.

Ritter, S. 2010. Lilies on the Land. Theatre Programme Arts Theatre, London.

Sackville West, V. 2004 (1926). The Land. London: First Frances Lincoln Edition.

Shore, R. 08/07/10. "Time Out London" in Theatre Record, Vol. XXX (12).

Sierz, A. 2011. Rewriting the Nation. British Theatre Today. London: Methuen.

Spencer, C. 17/06/10. "Daily Telegraph" in Theatre Record, Vol. XXX (12).

Weiss, P. 1971. "The Material and the Models: Notes Towards a Definition of Documentary Theatre", trans. Heinz Bernard, Theatre Quarterly, 1,1 (January-March). 